\title{
Article
}

\section{Psychopolitics Today: a response to Tad Tietze}

Cresswell, M and Spandler, Helen

Available at http://clok.uclan.ac.uk/11582/

Cresswell, M and Spandler, Helen ORCID: 0000-0002-0970-5141 (2015)

Psychopolitics Today: a response to Tad Tietze. Critical and Radical Social Work, 3 (1). pp. 119-125. ISSN 2049-8608

It is advisable to refer to the publisher's version if you intend to cite from the work. http://dx.doi.org/10.1332/204986015X14234701186062

For more information about UCLan's research in this area go to

http://www.uclan.ac.uk/researchgroups/ and search for < name of research Group>.

For information about Research generally at UCLan please go to http://www.uclan.ac.uk/research/

All outputs in CLoK are protected by Intellectual Property Rights law, including Copyright law. Copyright, IPR and Moral Rights for the works on this site are retained by the individual authors and/or other copyright owners. Terms and conditions for use of this material are defined in the policies page.

\section{CLoK}

Central Lancashire online Knowledge www.clok.uclan.ac.uk 


\title{
commentary
}

\section{Psychopolitics today: a response to Tad Tietze}

\author{
Mark Cresswell, Durham University, UK \\ mark.cresswell@durham.ac.uk
}

\section{Helen Spandler, University of Central Lancashire, Preston, UK hspandler@uclan.ac.uk}

We welcome Tad Tietze's recent work building upon the political legacy of Peter Sedgwick (Tietze, this issue) [[citation has now been added; should more of his work be cited?]]. Both Tietze and ourselves have been part of the recent resurgence of interest in Sedgwick, especially the relevance of his work to the politics of mental health. While our response here is quite critical, we are keen to be rowing in the same 'Sedgwickian' direction.

Although it is gratifying that Tietze calls us 'key inheritors' of Sedgwick's legacy, it is important to note that our own work is as much influenced by feminism as it is by socialism. Tietze is right to point to Sedgwick's support of the seminal 'Beyond the Fragments' conference of 1979, which led to the book of the same name shortly afterwards, an intervention that remains a stem text of socialist feminism today (Rowbotham et al, 1980). It is certain that Sedgwick was held in high esteem by many key socialist feminists of the time, yet the feminist influence is mostly absent in his work. This leads to our first concern: if our admiration for Sedgwick is this side of idolatry, we detect a certain reverence in Tietze, which is antithetical to Sedgwick's own open-ended socialism. A few examples will illustrate what we mean.

\section{Sedgwick on anti-psychiatry}

Tietze rearticulates Sedgwick's critiques of the 'great male minds' of anti-psychiatry (Foucault, Goffman, Laing and Szasz), critiques which, it has to be said, are initially very persuasive. Yet, while these critiques remain required reading, they do need reappraisal today.

Sedgwick had fun debunking R.D. Laing's mostly incoherent dalliance with the New Left of the 1960s. With typical courage, he also castigated the 1971 Lainginspired Ken Loach film Family life - courageous because of Loach's own left-wing credentials. But none of this should distract from the brilliance of Laing's The divided self and Self and others (Laing, 1960, 1966); nor should we minimise his penetrating appropriation not just of Jean-Paul Sartre's early existentialism (in Being and nothingness; Satre, 1943) but also of his later Marxist 'turn' (in the Critique of dialectical reason; Satre, 1960; Laing and Cooper, 1971).

Sedgwick's critique of Goffman is skilful but does basically just reiterate the previous objections of Gouldner's (1970) The coming crisis of Western sociology - that behind Goffman's incisive re-descriptions of 'deviance' (classically in Asylums; Goffman, 1961) lurks a radical chic that is more apparent than real and employs an impoverished 
concept of resistance to power. In Psychopolitics, Sedgwick (1982) makes great play with Goffman's 'methodological localism' but it is easy to re-read this, not as the indictment that Sedgwick intends, but as a signifier of Goffman's micro-sociological credentials. Indeed, Goffman's concern with micro-politics remains an important tool for research into mental health precisely because it is within interpersonal encounters that more structural social relations are experienced, especially by those subjected to psychiatric power.

Thomas Szasz was tellingly revealed by Sedgwick as a methodological individualist (and a social Darwinist). Szasz seems to have thought that his favoured epistemology, which he derived from Karl Popper, led automatically to a political philosophy of right-wing libertarianism and the most minimal strategy of state interventionism. As a socialist, Sedgwick was right to condemn Szasz's position, and Tietze is right to highlight this. But, again, this is not the end of the story. Serious reappraisals of Szasz's work have found his tenacity in opposing the oppressions of psychiatry and at least some aspects of his 'psychomedical dualism' - the insistence upon a strict separation of medicine and psychiatry - worth preserving. ${ }^{1}$ We have more to say about this separation in the closing section of this response.

The case of Foucault is more complex because Sedgwick did not live long enough to evaluate some of Foucault's later work on psychiatry in the now translated College de France lecture series of the 1970s, where the concern with psychiatric power intermingles with neoliberal strategies of the state or what Foucault (2008) called 'governmentality'. Although Left-inspired scholars have often critiqued Foucault, many have also sought to appropriate his insights about the power-knowledge stratagems of modernity into the Marxist tradition and that appropriation remains important for the theory and practice of 'psychopolitics'.

So, to sum up this section of our response, we would say that Tietze provides a good exposition of the central arguments of Sedgwick's (1982) critique in Psychopolitics. Given Tietze's work and our own, we think that Sedgwick's continued relevance to the politics of mental health is now firmly established. But we do detect an overreverence in Tietze, a hankering after the one-true authentic rendition of Sedgwick. We want to caution against this tendency and would not want Sedgwick's open-ended socialism to be crystallised into dogma. That is why we take his central critiques as a point of departure rather than the final word.

This brings us to Tietze's criticisms of our own work (Cresswell and Spandler, 2009) where we attempt to appraise Sedgwick's contribution in the light of recent developments, especially psychiatric survivor activism (the importance of which Sedgwick himself underestimated at the time).

\section{Tietze's critique}

Tietze mounts two specific critiques of our work that we would like to respond to. First, regarding our attempts to historicise Sedgwick's focus on an illness/disease paradigm by stressing, rather, a trauma/abuse/distress paradigm, Tietze (this issue: 0000) [[page number to be added at proof stage]] claims that we have elided how:

Sedgwick explained ... that 'however illness is specified from culture to culture, the attribution of illness appears to include a quest for explanation....' 


\begin{abstract}
Even if illness is reframed as 'trauma/abuse/distress', as long as individuals seek to address their suffering through engagement with some kind of treatment process, the shift entailed in the renaming of their problems is at most a move away from dominant biotechnological medical paradigms.... Their critical rejection of mainstream psychiatry's illness claims is thus coupled to uncritical belief that a terminological change breaks beyond socially constituted conceptions of health and illness in general.
\end{abstract}

There seem to be a number of confusions evident here. The first concerns how we understand 'renaming' manoeuvres (illness $>$ trauma) as aspects of political activism. The key point we would emphasise is that the social construction manifested in the practice of 'renaming' human experience is not somehow epiphenomenal to social reality but constitutes it, alongside all other aspects of that reality. According to this view, the paradigm shift signified by the move illness $>$ trauma is a form of what Crossley (2006) calls 'linguistic subversion' - it is part and parcel of a 'repertoire of contention' of activism alongside equally important non-linguistic practices. By implying that linguistic subversion is somehow epiphenomenal to the 'real' ontology of 'health and illness in general', Tietze is in danger of misrepresenting activism in mental health as a merely linguistic affair. Renaming experience is not just an academic exercise in textual deconstruction, but directly followed activism in the mental health field that was rooted in feminist and psychiatric survivor activism. This can be seen historically in the self-harm and hearing voices movements.

We detect in Tietze's account a rather reductionist and deterministic Marxism. This type of approach separates the 'base' and 'superstructure' and sees all the action that matters as being causally located in the 'base' (where 'health and illness in general' apparently reside) and everything else (the 'superstructure' including language) as epiphenomenal. We far prefer the flexible thinking of Sedgwick himself and the tradition of what has recently been called 'open' Marxism. To paraphrase Marx, the task is to continually analyse the rich totality of many social determinations in each new historical situation. This holds for the analysis of psychopolitics today.

This relates to the second critique of our work.

Tietze contends that we favour Szasz's 'psychomedical dualism' over Sedgwick's 'unitary' concept of illness in so far as 'physical medicine and psychiatry are qualitatively different because determinations of health and illness are directly bound up with the ... coercive imposition of treatment in psychiatry' (Tietze, this issue: 0000). [[page number to be added at proof stage]] Tietze finds this unsustainable on two grounds:

First, much of psychiatric practice has for decades expanded well outside the narrow remit of locked-ward practice.... Second, their claim does not acknowledge the wide range of coercive practices in physical medicine.... From the impossibility of 'informed consent' ... to the informally nonconsensual treatment of seriously ill patients in emergency and acute medical settings, to the use of various legal instruments like 'guardianship' orders to impose treatment and control on patients....

The problem here is that Tietze is introducing a dualism of his own, devising then deploying it to buttress his argument. True, it is no longer psychomedical dualism 
but, rather, a polemical dualism, which tries to win the argument by insisting that the reader must be either (a) a believer in the incommensurability of psychiatry and medicine like (allegedly) us and Szasz, or (b) a believer in their 'unitary' identity like Sedgwick and Tietze. Yet what unites Sedgwick and Szasz, despite their political differences, is the way in which they mobilise 'ideal-types' to motivate their analyses.

For Szasz, the ideal-type is 'psychomedical dualism'; for Sedgwick, it is the 'unitary' concept of illness. Ideal-types, following Weber (1978), represent an epistemological model of social reality (not reality itself). They are useful as tools of comparative analysis because they enable us to ask empirically relevant questions such as: 'In what way does social reality diverge from the ideal-type?' The downside is that they can become theoretical 'givens', even 'ideologies' that can never be questioned. E.P. Thompson (1978) once referred to this process as 'theoretical imperialism' - the shoe-horning of real-world observations into preconceived theoretical categories. Indeed, one of Sedgwick's most important criticisms of the so-called 'anti-psychiatrists' was their tendency to slot psychiatric sufferers into the general case offered by the latest radical-sounding ideology of the time, at the expense of the specific needs and circumstances of individuals concerned.

Rather than positing another opposition, we suggest that Szasz and Sedgwick's ideal-types inhabit two ends of a spectrum: complete incommensurability of psychiatry and medicine (Szaszian) at one end, and 'unitary' identity (Sedgwickian) at the other. This kind of approach enables us to address Tietze's questions concerning the contrast between psychiatry and medicine without succumbing to dualism. Armed with this approach, we can respond to Tietze's objections as follows.

First, while it is undoubtedly true that much of psychiatric practice has expanded well outside the narrow remit of locked-ward practice, we do not think that this invalidates our claims. Deploying our approach we would say that if forensic psychiatry seems to be situated towards the Szaszian end of our spectrum, then, let us say a consultation with a general practitioner over lack of sleep and ruminations of worthlessness is closer to a similar consultation for physical illness. There are elements of commonality in the comparison but also differences. Indeed, exerting such control over ideal-types is important for our own research into, for example, deliberate selfharm and accident and emergency departments. In this example, the discriminatory practices to which self-harmers have been historically subjected suggest a marked contrast to the treatment, say, of a road traffic victim or someone who suffers from a myocardial infarction although all occur within a general medical setting. Again, the flexible approach deployed lends itself to a nuanced analysis of both sameness and difference within psychiatry and between psychiatry and general medicine.

Second, while we do not deny the existence of coercive practices in physical medicine, again Tietze's analysis of psychiatry and general medicine is being shoehorned into the theoretical armoury of Sedgwick's 'unitary' concept of illness. Given the approach we advocate, we would rather suggest that such contrasts be empirically investigated. For example, the use of Community Treatment Orders in the United Kingdom, introduced in the revision to the Mental Health Act in 2007, could be contrasted with 'safeguarding'-related decisions driven by the Mental Capacity Act 2005. Once more, the analysis would be nuanced, emphasising both sameness and difference. The theoretical and empirical aspects of the analysis would exist in dialectical relation and not as a way of shoe-horning social reality into preordained theoretical categories. 
To conclude, we welcome Tietze's continued commitment to Sedgwickian psychopolitics. But, we think that Sedgwick's work should be treated as a point of departure rather than a terminus for analysis and political action. It is a stem text, for us, not a blueprint. We welcome discussion - open-ended, of course - about the issues raised by Tietze's paper and our response.

\section{Note}

${ }^{1}$ See the special issue of Asylum magazine devoted to an appraisal of Szasz's work (Asylum, 2013).

\section{References}

Asylum: the magazine for democratic psychiatry (2013) Thomas Szasz: 1920-2012, 20, 1

Cresswell, M, Spandler, H, 2009, Psychopolitics: Peter Sedgwick's legacy for mental health movements, Social Theory and Health, 7, 2, 129-47

Crossley, N, 2006, Contesting psychiatry: Social movements in mental health, London: Routledge

Foucault, M, 2008, Psychiatric power: Lectures at the College de France, 1973-1974, New York, NY: Picador

Goffman, E, 1961, Asylums: Essays on the social situation of mental patients and other inmates, Garden City, NY: Anchor Books

Gouldner, AW, 1970, The coming crisis of Western sociology, New York, NY: Basic Books Laing, RD, 1960, The divided self: An existential study in sanity and madness, London: Tavistock

Laing, RD, 1966, Self and others, Harmondsworth: Penguin Books

Laing, RD, Cooper, D, 1971, Reason and violence: A decade of Sartre's philosophy 19501960, New York, NY: Vintage Books

Rowbotham, S, Segal, L, Wainwright, H, 1980, Beyond the fragments: Feminism and the making of socialism, London: Merlin

Satre, J-P, 1943 Being and nothingness, Paris: Gallimard.

Satre, J-P, 1960, Critiques of dialectical reason, Paris: Gallimard.

Sedgwick, P, 1982, Psychopolitics, London: Pluto Press

Thompson, EP, 1978, The poverty of theory and other essays, London: Merlin Press

Weber, M, 1978, Economy and society: An outline of interpretive sociology, Berkeley, CA: University of California Press 